\title{
Pseudidiomarina marina sp. nov. and Pseudidiomarina tainanensis sp. nov. and reclassification of Idiomarina homiensis and Idiomarina salinarum as Pseudidiomarina homiensis comb. nov. and Pseudidiomarina salinarum comb. nov., respectively
}

\author{
Wen Dar Jean, ${ }^{1}$ Tsung-Yen Leu, ${ }^{2}$ Chung-Yi Lee, ${ }^{2}$ Ta-Jen Chu, ${ }^{3}$ \\ Silk Yu Lin ${ }^{4}$ and Wung Yang Shieh ${ }^{4}$ \\ ${ }^{1}$ Center for General Education, Leader University, No. 188, Sec. 5, An-Chung Rd, Tainan, Taiwan, \\ $\mathrm{ROC}$ \\ ${ }^{2}$ Department of Microbiology, Soochow University, Taipei, Taiwan, ROC \\ ${ }^{3}$ Department of Leisure and Recreational Management, Chung Hua University, 30, Tung-Hsiang, \\ Hsinchu, Taiwan, ROC \\ ${ }^{4}$ Institute of Oceanography, National Taiwan University, PO Box 23-13, Taipei, Taiwan, ROC
}

Correspondence Wung Yang Shieh winyang@ntu.edu.tw
Two Gram-negative strains of heterotrophic, aerobic, marine bacteria, designated $\mathrm{PIM} 1^{\top}$ and $\mathrm{PIN}^{\top}{ }^{\top}$, were isolated from seawater samples collected from the shallow coastal region of An-Ping Harbour, Tainan, Taiwan. Cells grown in broth cultures were straight rods and non-motile. The two isolates required $\mathrm{NaCl}$ for growth and grew optimally at $30-35{ }^{\circ} \mathrm{C}$ and $2-5 \% \mathrm{NaCl}$. They grew aerobically and were not capable of anaerobic growth by fermentation of glucose or other carbohydrates. The cellular fatty acids were predominantly iso-branched, with iso- $\mathrm{C}_{15: 0}(17.0-$ $21.4 \%)$, iso- $\mathrm{C}_{17: 0}(18.2-21.0 \%)$ and iso- $\mathrm{C}_{17: 1} \omega 9 \mathrm{c}(15.7-16.6 \%)$ as the most abundant components. The predominant isoprenoid quinone was Q-8 (95.2-97.1\%). Strains $\mathrm{PIM} 1^{\top}$ and $\mathrm{PIN}^{\top}{ }^{\top}$ had DNA G $+\mathrm{C}$ contents of 46.6 and 46.9 mol\%, respectively. Phylogeny based on $16 \mathrm{~S}$ rRNA gene sequences and DNA-DNA hybridization, together with data from physiological, morphological and chemotaxonomic characterizations, indicated that the two isolates should be classified as representatives of two novel species of the genus Pseudidiomarina of the family Idiomarinaceae, for which the names Pseudidiomarina marina sp. nov. (type strain $\mathrm{PIM} 1^{\top}=\mathrm{BCRC}$ $17749^{\top}=\mathrm{JCM} 15083^{\top}$ ) and Pseudidiomarina tainanensis sp. nov. (type strain $\mathrm{PIN1} 1^{\top}=\mathrm{BCRC}$ $17750^{\top}=\mathrm{JCM} 15084^{\top}$ ) are proposed. In addition, based on the characterization data obtained in this study, it is proposed that Idiomarina homiensis and Idiomarina salinarum should be reclassified as Pseudidiomarina homiensis comb. nov. and Pseudidiomarina salinarum comb. nov., respectively.
The family Idiomarinaceae (Ivanova et al., 2004; Jean et al., 2006), in the class Gammaproteobacteria, comprises halophilic, aerobic, Gram-negative, rod-shaped bacteria that have a high content of iso-branched cellular fatty acids. This family is currently comprised of the genera Idiomarina (Ivanova et al., 2000) and Pseudidiomarina (Jean et al., 2006). At the time of writing, the genus Idiomarina contained nine recognized species, Idiomarina

The GenBank/EMBL/DDBJ accession numbers for the 16S rRNA gene sequences of strains $\mathrm{PIM}^{\top}{ }^{\top}$ and $\mathrm{PIN} 1^{\top}$ are EU423908 and EU423907, respectively. abyssalis (Ivanova et al., 2000), I. baltica (Brettar et al., 2003), I. fontislapidosi (Martínez-Cánovas et al., 2004), I. homiensis (Kwon et al., 2006), I. loihiensis (Donachie et al., 2003), I. ramblicola (Martínez-Cánovas et al., 2004), I. salinarum (Yoon et al., 2007), I. seosinensis (Choi \& Cho, 2005) and I. zobellii (Ivanova et al., 2000), whereas the genus Pseudidiomarina contained only two recognized species, Pseudidiomarina taiwanensis (Jean et al., 2006) and P. sediminum ( $\mathrm{Hu} \& \mathrm{Li}, 2007)$. These bacteria were isolated from saline habitats with a wide range of salinities, such as coastal and oceanic waters, coastal sediments, submarine hydrothermal fluids, solar salterns and inland hypersaline 
wetlands. Members of Idiomarina and Pseudidiomarina have been defined as possessing signature nucleotides (numbering by comparison with Escherichia coli sequence AE000471) 662 (A), 682 (A), 830 (T) and 856 (A). Members of Idiomarina have an additional signature nucleotide $\mathrm{C}$ at position 143, whereas members of Pseudidiomarina have a signature nucleotide A instead of $\mathrm{C}$ at this sequence position (Jean et al., 2006).

In the present study, two bacterial isolates were recovered from seawater samples collected from the shallow coastal region of An-Ping Harbour, Tainan, Taiwan, during a survey of the diversity of phenanthrene-degrading bacteria. Data from a polyphasic characterization indicated that the two isolates could be classified as representing two novel species of the genus Pseudidiomarina.

The mineral/phenanthrene (MP) liquid medium used for enrichment cultivation of phenanthrene-degrading bacteria contained the following (per litre deionized water): $0.54 \mathrm{~g}$ $\mathrm{NH}_{4} \mathrm{Cl}, 30 \mathrm{~g} \mathrm{NaCl}, 3 \mathrm{~g} \mathrm{MgCl} 2.6 \mathrm{H}_{2} \mathrm{O}, 2 \mathrm{~g} \mathrm{~K}_{2} \mathrm{SO}_{4}, 0.2 \mathrm{~g}$ $\mathrm{K}_{2} \mathrm{HPO}_{4}, \quad 0.01 \mathrm{~g} \quad \mathrm{CaCl}_{2}, 0.006 \mathrm{~g} \quad \mathrm{FeCl}_{3} \cdot 6 \mathrm{H}_{2} \mathrm{O}, 0.005 \mathrm{~g}$ $\mathrm{Na}_{2} \mathrm{MoO}_{4} \cdot 7 \mathrm{H}_{2} \mathrm{O}, 0.004 \mathrm{~g} \mathrm{CuCl} \cdot 2 \mathrm{H}_{2} \mathrm{O}, 6 \mathrm{~g}$ Tris and $1 \mathrm{~g}$ phenanthrene. The medium was adjusted to $\mathrm{pH}$ 8.0. Other culture media used were as described by Shieh et al. (2000).

An-Ping Harbour is located on the south-west coast of Taiwan. Seawater samples were collected from the shallow coastal region of this harbour in the morning at low tide. Aliquots $(1 \mathrm{ml})$ of the seawater samples were transferred to culture bottles containing MP medium $(50 \mathrm{ml})$. All culture bottles were incubated aerobically at $30{ }^{\circ} \mathrm{C}$ in the dark for 2-3 weeks. Cultures in bottles that developed visible turbidity were streaked on polypeptone-yeast (PY) plate medium (Shieh et al., 2000). Individual colonies that appeared on the plates were picked off and purified by successive streaking on PY plates. PY stab cultures of the isolates were maintained at $25{ }^{\circ} \mathrm{C}$ under aerobic conditions. Two of the isolates, designated strains $\mathrm{PIM}^{\mathrm{T}}$ and $\mathrm{PIN} 1^{\mathrm{T}}$, were deposited in the Bioresource Collection and Research Center (BCRC) and the Japan Collection of Micro-organisms (JCM) as lyophilized cultures, and were used in this study. It should be noted that strains PIM1 ${ }^{\mathrm{T}}$ and PIN1 $1^{\mathrm{T}}$ were not able to grow in MP medium as pure cultures, in spite of the fact that they were isolated from enrichment cultures with phenanthrene as the sole carbon source. However, it was unclear whether these isolates had grown in the initial enrichment cultures by utilizing metabolite(s) produced by co-existing phenanthrenedegrading bacteria, or whether the isolates had lost their phenanthrene-degrading ability after being grown on the non-selective PY plate medium.

Growth and other phenotypic properties used for the morphological and physiological characterization of strains $\mathrm{PIM}^{\mathrm{T}}$ and PIN1 $1^{\mathrm{T}}$ were determined following the established procedures described by Jean et al. (2006).

Fatty acids of whole cells grown on PY plate medium at $30{ }^{\circ} \mathrm{C}$ for 3 days were extracted, saponified and esterified.
The fatty acid methyl esters were analysed by using GC, according to the protocol of the MIDI system (Sasser, 1997). This work was performed at the BCRC. Determination of the DNA G+C content by HPLC analysis (Shieh \& Liu, 1996) was also performed at the BCRC. Isoprenoid quinones were extracted, purified and analysed by using an HPLC apparatus equipped with a reversed-phase column (Shieh et al., 2008).

DNA-DNA hybridization was performed between strains $\mathrm{PIM}^{\mathrm{T}}$ and PIN1 ${ }^{\mathrm{T}}$. Bacterial DNA was isolated and extracted using the method of Smibert \& Krieg (1994). The DNA was blotted on a Hybond- ${ }^{+}$membrane (Amersham Pharmacia Biotech) using a Bio-Dot microfiltration apparatus (Bio-Rad Laboratories). The dot-blot hybridization was carried out at $68{ }^{\circ} \mathrm{C}$ (Fesefeldt et al., 1998). Total genomic DNA of strain PIM1 $1^{\mathrm{T}}$ labelled using a DIG DNA labelling kit (Roche Diagnostics) was used as the probe. Hybridization was determined by using an enzyme immunoassay and enzyme-catalysed colour reaction with a DIG nucleic acid detection kit (Boehringer Mannheim). The DNA-DNA relatedness between strains $\mathrm{PIM}^{\mathrm{T}}$ and $\mathrm{PIN1}^{\mathrm{T}}$ was estimated according to the hybridization results obtained using 1D Image Analysis software (Kodak).

Cells grown in PY broth at $30{ }^{\circ} \mathrm{C}$ for 3 days were harvested by centrifugation. The methods described by Jean et al. (2006) were followed for the extraction and purification of total genomic DNA and for PCR amplification of the 16S rRNA genes. Sequencing of the $16 \mathrm{~S}$ rRNA genes, alignment and comparison of the resulting sequences with reference sequences available in the GenBank database, calculation of distance matrices for the aligned sequences and reconstruction of phylogenetic trees using the neighbour-joining, maximum-parsimony and maximum-likelihood methods were performed as described previously (Shieh et al., 2004; Jean et al., 2006). The stability of clusters was evaluated by using a bootstrap analysis with 1000 resamplings.

Nearly complete 16S rRNA gene sequences were determined for strains PIM1 ${ }^{\mathrm{T}}$ and PIN $1^{\mathrm{T}}$ (1465 nt for each). The two sequences were aligned and compared with bacterial sequences available in the GenBank database. The two sequences had $98.6 \%$ sequence similarity (21 out of 1465 nt positions). Phylogeny based on a neighbour-joining analysis of the 16S rRNA gene sequences revealed that strains $\mathrm{PIM}^{\mathrm{T}}$ and $\mathrm{PIN1}^{\mathrm{T}}$ were members of the family Idiomarinaceae in the class Gammaproteobacteria and that the two novel isolates formed a robust cluster (bootstrap value, $95.4 \%$ ) with $P$. taiwanensis $\mathrm{PIT}^{\mathrm{T}}$ and $P$. sediminum $\mathrm{c} 21^{\mathrm{T}}$, their closest neighbours, together with I. homiensis $\mathrm{PO}-\mathrm{M} 2^{\mathrm{T}}$ and I. salinarum ISL-52 ${ }^{\mathrm{T}}$ (Fig. 1). Similar results were obtained using the maximum-likelihood and maximum-parsimony algorithms (data not shown). Strains $\mathrm{PIM}^{\mathrm{T}}$ and $\mathrm{PIN1}^{\mathrm{T}}$ showed 94.7-96.5\% $16 \mathrm{~S}$ rRNA gene sequence similarities to their closest neighbours and 91.1$94.4 \%$ sequence similarities with other Idiomarina species. Bacterial species that were not members of the family 


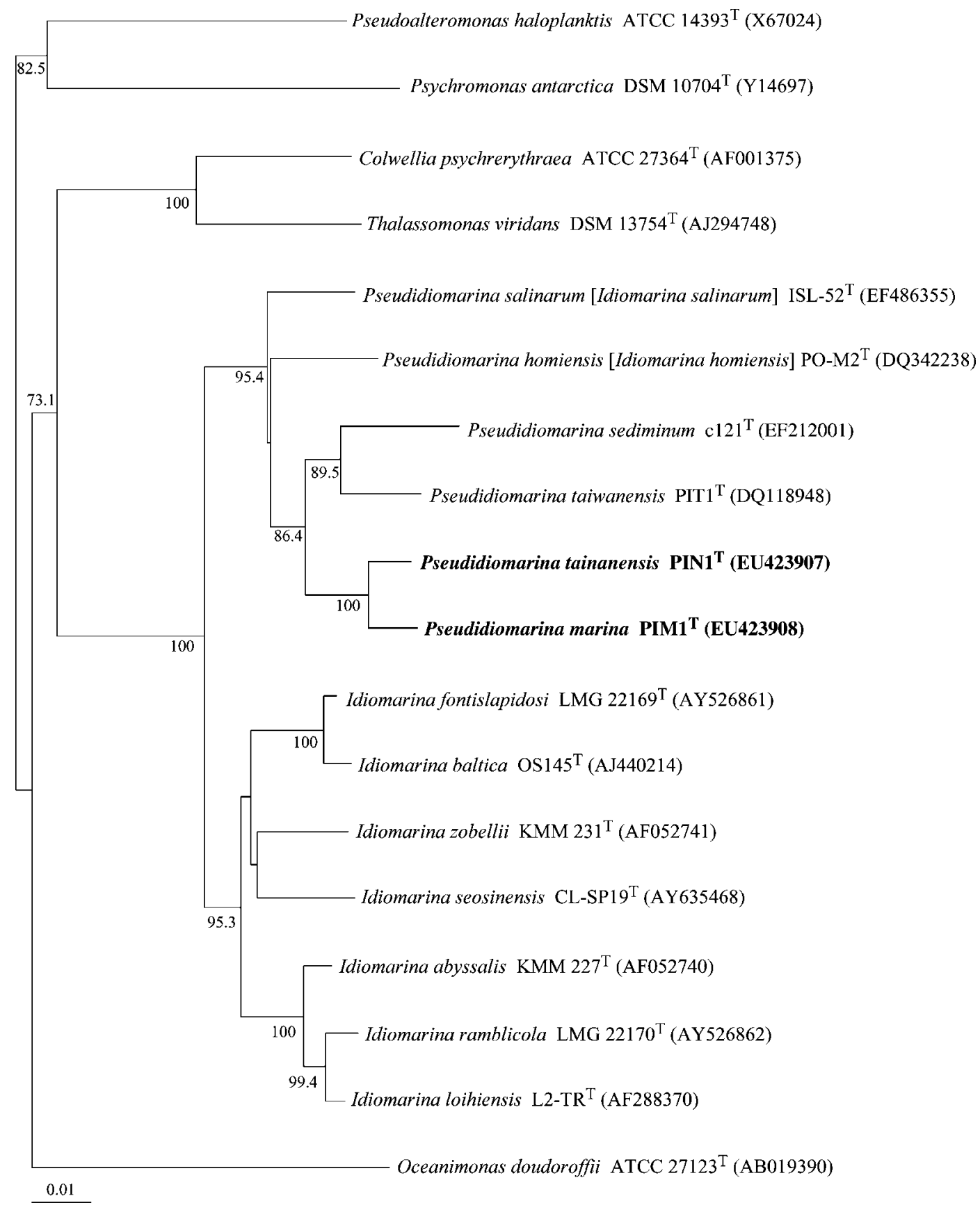

Fig. 1. Unrooted phylogenetic tree derived from a neighbour-joining analysis of $16 \mathrm{~S}$ rRNA gene sequences, showing the relationship between strains $\mathrm{PIM} 1^{\top}$ and $\mathrm{PIN} 1^{\top}$ and recognized species of the family ldiomarinaceae, together with some other related taxa belonging to the Gammaproteobacteria. GenBank accession numbers are given in parentheses. Only bootstrap values greater than $70 \%$ are shown at branch nodes (based on 1000 replications). Bar, 0.01 substitutions per nucleotide position.

Idiomarinaceae had sequence similarities of less than $90.5 \%$ with the two novel isolates. The $16 \mathrm{~S}$ rRNA genebased phylogeny indicated that strains PIM1 ${ }^{\mathrm{T}}$ and $\mathrm{PIN}^{\mathrm{T}}$ could be classified as representing novel members of the genus Pseudidiomarina. Moreover, the data also suggested that I. homiensis $\mathrm{PO}-\mathrm{M} 2^{\mathrm{T}}$ and I. salinarum $\mathrm{ISL}-52^{\mathrm{T}}$ should be reclassified as belonging to the genus Pseudidiomarina, as they clustered with species of Pseudidiomarina rather than with those of Idiomarina. The finding that strains PO$\mathrm{M}^{\mathrm{T}}$ and ISL-52 ${ }^{\mathrm{T}}$ had nucleotide $\mathrm{A}$, instead of $\mathrm{C}$, at position 143 further indicated that they should be reclassified as Pseudidiomarina species. 
Strains $\mathrm{PIM}^{\mathrm{T}}$ and $\mathrm{PIN1}^{\mathrm{T}}$, as for species of the genera Pseudidiomarina and Idiomarina in the family Idiomarinaceae, contained iso- $\mathrm{C}_{15: 0}(17.0-21.4 \%)$ and iso- $\mathrm{C}_{17: 0}$ $(18.2-21.0 \%)$ as the major cellular fatty acids (Table 1). However, the fatty acid profiles of the two novel isolates could be distinguished from those of other species of the family Idiomarinaceae. This was shown by differences in the levels of the fatty acids iso- $\mathrm{C}_{19: 0}(3.5-3.6 \%$ versus $0 \%)$ and iso- $\mathrm{C}_{17: 1} \omega 9 c(15.7-16.6 \%$ versus $0-11.9 \%)$. Other quantitative differences in the fatty acids that serve to differentiate the two novel isolates from other Idiomarinaceae species are given in Table 1 . The fatty acid profiles of strains $\mathrm{PIM1}^{\mathrm{T}}$ and $\mathrm{PIN1}^{\mathrm{T}}$ were similar. However, only strain $\mathrm{PIM1}^{\mathrm{T}}$ contained trace amounts of $\mathrm{C}_{10: 0}, \mathrm{C}_{16: 1} \omega 9 c$ and $\mathrm{C}_{19: 0} \omega 8 c$ cyclo, whereas only strain $\mathrm{PIN}_{1}^{\mathrm{T}}$ contained trace amounts of anteiso- $\mathrm{C}_{15: 0}$ and 11-methyl $\mathrm{C}_{18: 1} \omega 7 c$. Strains PIM1 $^{\mathrm{T}}$ and $\mathrm{PIN1}^{\mathrm{T}}$ contained Q-8 as the predominant isoprenoid quinone $\left(95.2 \%\right.$ for $\mathrm{PIM}^{\mathrm{T}}$ and $97.1 \%$ for $\left.\mathrm{PIN1}^{\mathrm{T}}\right)$ and Q7 as a minor one $\left(4.8 \%\right.$ for PIM1 ${ }^{\mathrm{T}}$ and $2.9 \%$ for $\left.\mathrm{PIN}^{\mathrm{T}}{ }^{\mathrm{T}}\right)$. The DNA G $+C$ contents of strains PIM1 ${ }^{\mathrm{T}}(46.6 \mathrm{~mol} \%)$ and $\mathrm{PIN1}^{\mathrm{T}}$ (46.9 mol\%) fell within the range of values reported for known Idiomarinaceae species (45.0-53.9 mol\%), but were slightly lower than those of $P$. taiwanensis (48.6$49.3 \mathrm{~mol} \%)$ and P. sediminum (50.0 mol\%). DNA-DNA hybridization results showed that strains $\mathrm{PIM}^{\mathrm{T}}$ and $\mathrm{PIN} 1^{\mathrm{T}}$ had a relatedness value of $18.4 \%$.

Table 1. Cellular fatty acid contents (\%) of strains $\mathrm{PIM} 1^{\top}$ and $\mathrm{PIN} 1^{\top}$ and type strains of recognized Idiomarinaceae species

Strains: $1, \mathrm{PIM}^{\mathrm{T}}$ (P. marina sp. nov.; data from this study); 2, PIN1 ${ }^{\mathrm{T}}$ (P. tainanensis sp. nov.; this study); 3, P. sediminum $\mathrm{cl}^{2} 1^{\mathrm{T}}$ (Hu \& Li, 2007); 4, P. taiwanensis $\mathrm{PIT}^{\mathrm{T}}$ and PIT2 (Jean et al., 2006); 5, I. salinarum ISL-52 ${ }^{\mathrm{T}}$ (Yoon et al., 2007); 6, I. homiensis PO-M2 ${ }^{\mathrm{T}}$ (Kwon et al., 2006); 7, I. baltica $\mathrm{OS}_{145^{\mathrm{T}}}$ (Brettar et al., 2003); 8, I. loihiensis L2-TR ${ }^{\mathrm{T}}$ (Donachie et al., 2003); 9, I. fontislapidosi L23 ${ }^{\mathrm{T}}$ (Martínez-Cánovas et al., 2004); 10, I. seosinensis CL-SP19 ${ }^{\mathrm{T}}$ (Choi \& Cho, 2005); 11, I. ramblicola R22 ${ }^{\mathrm{T}}$ (Martínez-Cánovas et al., 2004); 12, I. abyssalis KMM $227^{\mathrm{T}}$ (Ivanova et al., 2000); 13, I. zobellii KMM $231^{\mathrm{T}}$ (Ivanova et al., 2000). - , Not detected/not reported; tr, trace amount detected $(<1 \%)$.

\begin{tabular}{|c|c|c|c|c|c|c|c|c|c|c|c|c|c|}
\hline Fatty acid & 1 & 2 & 3 & 4 & 5 & 6 & 7 & 8 & 9 & 10 & 11 & 12 & 13 \\
\hline $\mathrm{C}_{10: 0}$ & $\operatorname{tr}$ & - & $\operatorname{tr}$ & $\operatorname{tr}$ & - & - & - & - & - & - & - & - & - \\
\hline $\mathrm{C}_{10: 0} 3-\mathrm{OH}$ & $\operatorname{tr}$ & $\operatorname{tr}$ & 1.3 & $\operatorname{tr}$ & - & 1.2 & 1.2 & $\operatorname{tr}$ & 2.3 & 1.3 & 1.1 & - & - \\
\hline iso- $\mathrm{C}_{11: 0}$ & 1.8 & 2.1 & $\operatorname{tr}$ & $2.2-2.4$ & 4.2 & 1.8 & 2.5 & 2.0 & 2.8 & 3.2 & 3.4 & - & - \\
\hline iso- $\mathrm{C}_{11: 0} 3-\mathrm{OH}$ & 4.5 & 4.8 & 4.3 & $4.2-4.6$ & 5.0 & 4.4 & 3.7 & 4.1 & 2.6 & 5.0 & 5.6 & - & - \\
\hline $\mathrm{C}_{12: 0}$ & $\operatorname{tr}$ & $\operatorname{tr}$ & $\operatorname{tr}$ & $\operatorname{tr}$ & - & - & - & - & - & - & - & - & - \\
\hline $\mathrm{C}_{12: 0} 3-\mathrm{OH}$ & 1.0 & $\operatorname{tr}$ & 1.3 & $\operatorname{tr}$ & - & - & - & $\operatorname{tr}$ & - & 1.2 & - & - & - \\
\hline $\mathrm{C}_{13: 0}$ & - & - & - & $\operatorname{tr}$ & - & - & - & - & - & - & - & - & - \\
\hline iso- $\mathrm{C}_{13: 0}$ & 1.3 & 1.7 & 1.8 & $4.2-4.6$ & 1.6 & - & $\operatorname{tr}$ & 1.8 & $\operatorname{tr}$ & - & 1.5 & 1.0 & 1.1 \\
\hline iso- $\mathrm{C}_{13: 0} 3-\mathrm{OH}$ & 3.3 & 4.0 & 4.0 & $2.9-3.8$ & 5.0 & 3.6 & 3.2 & 3.3 & 1.6 & 4.2 & 2.3 & - & - \\
\hline $\mathrm{C}_{14: 0}$ & $\operatorname{tr}$ & $\operatorname{tr}$ & 1.1 & tr to 1.2 & - & - & - & $\operatorname{tr}$ & 1.9 & $\operatorname{tr}$ & $\operatorname{tr}$ & - & - \\
\hline $\mathrm{C}_{14: 1} \omega 5 c$ & - & - & $\operatorname{tr}$ & - & - & - & - & - & - & 1.4 & - & - & - \\
\hline anteiso- $\mathrm{C}_{15: 0}$ & - & $\operatorname{tr}$ & - & $\operatorname{tr}$ & - & - & - & $\operatorname{tr}$ & $\operatorname{tr}$ & - & 1.2 & - & - \\
\hline iso- $\mathrm{C}_{15: 1} \mathrm{~F}$ & 3.4 & 2.7 & 2.5 & $5.7-5.9$ & 3.9 & 1.7 & 1.5 & 1.3 & 1.5 & $\operatorname{tr}$ & 1.9 & 2.3 & 1.6 \\
\hline iso- $\mathrm{C}_{15: 0}$ & 17.0 & 21.4 & 24.2 & $31.7-37.8$ & 34.1 & 19.3 & 36.9 & 32.6 & 26.8 & 17.1 & 24.7 & 33.7 & 40.6 \\
\hline $\mathrm{C}_{15: 1} \omega 8 c$ & - & - & - & - & - & - & - & - & - & - & - & 1.3 & 1.1 \\
\hline iso- $\mathrm{C}_{15: 0} 3-\mathrm{OH}$ & - & - & - & - & - & - & - & $\operatorname{tr}$ & - & 1.2 & - & - & - \\
\hline$C_{16: 0}$ & 4.2 & 3.4 & 5.7 & $4.4-8.1$ & 4.3 & 9.0 & 4.8 & 7.6 & 11.7 & 8.9 & 7.4 & 6.3 & 4.6 \\
\hline iso- $\mathrm{C}_{16: 0}$ & $\operatorname{tr}$ & $\operatorname{tr}$ & $\operatorname{tr}$ & - & 1.3 & - & - & - & - & - & - & - & - \\
\hline $\mathrm{C}_{16: 1} \omega 7 c /$ iso- $\mathrm{C}_{15: 0} 2-\mathrm{OH}$ & 3.7 & 3.6 & 15.3 & $4.9-5.9$ & - & 7.2 & 8.4 & 6.0 & 11.3 & 2.5 & 5.2 & 7.0 & 8.3 \\
\hline $\mathrm{C}_{16: 1} \omega 9 c$ & $\operatorname{tr}$ & - & 1.0 & - & - & - & - & - & - & - & - & - & - \\
\hline $\mathrm{C}_{17: 0}$ & 1.0 & $\operatorname{tr}$ & $\operatorname{tr}$ & $\operatorname{tr}$ & - & - & - & $\operatorname{tr}$ & $\operatorname{tr}$ & $\operatorname{tr}$ & 1.7 & - & - \\
\hline iso- $\mathrm{C}_{17: 0}$ & 18.2 & 21.0 & 9.4 & $11.4-14.4$ & 19.9 & 10.9 & 11.2 & 11.0 & 8.8 & 15.2 & 12.9 & 11.9 & 12.5 \\
\hline $\mathrm{C}_{17: 1} \omega 6 c$ & - & - & - & - & - & - & - & - & - & - & - & 1.5 & 3.4 \\
\hline $\mathrm{C}_{17: 1} \omega 8 c$ & $\operatorname{tr}$ & $\operatorname{tr}$ & 1.6 & $\operatorname{tr}$ & - & - & $\operatorname{tr}$ & $\operatorname{tr}$ & $\operatorname{tr}$ & - & 1.1 & $\operatorname{tr}$ & 1.1 \\
\hline iso- $\mathrm{C}_{17: 1} \omega 9 c$ & 16.6 & 15.7 & 11.9 & $7.9-8.3$ & 11.8 & 11.9 & 10.0 & 11.9 & 4.0 & 8.8 & 11.0 & - & - \\
\hline $\mathrm{C}_{17: 0}$ cyclo & 1.3 & $\operatorname{tr}$ & $\operatorname{tr}$ & - & 1.7 & $\operatorname{tr}$ & $\operatorname{tr}$ & 1.7 & 1.2 & 4.5 & 2.5 & - & - \\
\hline $\mathrm{C}_{18: 0}$ & 7.9 & 4.7 & $\operatorname{tr}$ & $2.0-3.0$ & $\operatorname{tr}$ & 4.8 & $\operatorname{tr}$ & 1.6 & 4.9 & 3.9 & 3.0 & 1.8 & $\operatorname{tr}$ \\
\hline $\mathrm{C}_{18: 1} \omega 7 c$ & 5.5 & 3.4 & 6.9 & $1.9-3.4$ & $\operatorname{tr}$ & 10.4 & 6.0 & 5.5 & 9.3 & 8.7 & 5.9 & 6.7 & 5.9 \\
\hline $\mathrm{C}_{18: 1} \omega 9 c$ & 1.4 & 1.0 & 1.9 & $\operatorname{tr}$ & - & 2.5 & $\operatorname{tr}$ & 1.0 & 1.1 & $\operatorname{tr}$ & 1.2 & 1.4 & $\operatorname{tr}$ \\
\hline 11-methyl $\mathrm{C}_{18: 1} \omega 7 c$ & - & $\operatorname{tr}$ & - & - & - & - & 1.8 & - & $\operatorname{tr}$ & - & $\operatorname{tr}$ & - & - \\
\hline $\mathrm{C}_{18: 3} \omega 6 c(6,9,12)$ & - & - & - & - & - & - & - & - & - & 1.2 & - & - & - \\
\hline iso- $\mathrm{C}_{19: 0}$ & 3.5 & 3.6 & - & - & - & - & - & - & - & - & - & - & - \\
\hline $\mathrm{C}_{19: 1} \omega 6 c$ & - & - & - & - & - & - & $\operatorname{tr}$ & $\operatorname{tr}$ & - & 2.1 & - & - & - \\
\hline $\mathrm{C}_{19: 0} \omega 8 \mathrm{c}$ cyclo & $\operatorname{tr}$ & - & - & - & $\operatorname{tr}$ & - & - & - & - & 3.5 & - & - & - \\
\hline
\end{tabular}


Phylogeny based on $16 \mathrm{~S}$ rRNA gene sequences, analyses of isoprenoid quinones and fatty acids and DNA-DNA hybridization data indicated that the two isolates described here could be assigned to the genus Pseudidiomarina as representing two novel species. The names Pseudidiomarina marina sp. nov. and Pseudidiomarina tainanensis sp. nov. are proposed, with $\mathrm{PIM} 1^{\mathrm{T}}$ and $\mathrm{PIN1} 1^{\mathrm{T}}$, respectively, as the type strains. It is also proposed that I. homiensis and I. salinarum should be reclassified as Pseudidiomarina homiensis comb. nov. and Pseudidiomarina salinarum comb. nov., respectively.

Strains PIM1 $1^{\mathrm{T}}$ and $\mathrm{PIN1} 1^{\mathrm{T}}$ shared many physiological and morphological characteristics. However, the two strains could be differentiated from each other by different colony colours and by different reactions in the tests for hydrolysis of DNA and susceptibility to the antibiotics carbenicillin, chloramphenicol, cephalothin, gentamicin, erythromycin, nalidixic acid, neomycin, penicillin G, vancomycin and tetracycline. The ability to grow at $10{ }^{\circ} \mathrm{C}$ and $\mathrm{pH} 6$ and the inability to hydrolyse Tween 80 differentiated strains $\mathrm{PIM}^{\mathrm{T}}$ and $\mathrm{PIN}^{\mathrm{T}}$ from $P$. taiwanensis and $P$. sediminum. Cells of strains PIM1 ${ }^{\mathrm{T}}$ and $\mathrm{PIN}_{1}{ }^{\mathrm{T}}$ were non-motile, which allowed the two novel species to be distinguished from the motile, polar-flagellated Idiomarinaceae species, including I. abyssalis, I. baltica, I. fontislapidosi, P. homiensis comb. nov. [I. homiensis], I. loihiensis, I. ramblicola, I. seosinensis and I. zobellii. Additional characteristics useful for differentiating strains $\mathrm{PIM}^{\mathrm{T}}$ and $\mathrm{PIN1}^{\mathrm{T}}$ from other Idiomarinaceae species are given in Table 2. Details of the characterization data for strains $\mathrm{PIM}^{\mathrm{T}}$ and $\mathrm{PIN} 1^{\mathrm{T}}$ are given in the species descriptions.

\section{Description of Pseudidiomarina marina sp. nov.}

Pseudidiomarina marina (ma.ri'na. L. fem. adj. marina of the sea, marine).

Table 2. Characteristics that distinguish strains $\mathrm{PIM} 1^{\top}$ and $\mathrm{PIN1} 1^{\top}$ from recognized species of the family ldiomarinaceae

Strains: $1, \mathrm{PIM}^{\mathrm{T}}$ (P. marina sp. nov.; data from this study); 2, $\mathrm{PIN}^{\mathrm{T}}$ (P. tainanensis sp. nov.; this study); $3, P$. sediminum $\mathrm{cl} 21^{\mathrm{T}}$ (Hu \& Li, 2007); 4 , P. taiwanensis $\mathrm{PIT}^{\mathrm{T}}$ and PIT2 (Jean et al., 2006); 5, I. salinarum ISL-52 ${ }^{\mathrm{T}}$ (Yoon et al., 2007); 6, I. homiensis PO-M2 ${ }^{\mathrm{T}}$ (Kwon et al., 2006); 7, I. baltica $\mathrm{OS}_{145^{\mathrm{T}}}$ (Brettar et al., 2003); 8, I. loihiensis L2-TR ${ }^{\mathrm{T}}$ (Donachie et al., 2003); 9, I. fontislapidosi L23 ${ }^{\mathrm{T}}$ (Martínez-Cánovas et al., 2004); 10, I. seosinensis CL-SP19 ${ }^{\mathrm{T}}$ (Choi \& Cho, 2005); 11, I. ramblicola R22 ${ }^{\mathrm{T}}$ (Martínez-Cánovas et al., 2004); 12, I. abyssalis KMM 227 ${ }^{\mathrm{T}}$ (Ivanova et al., 2000); 13, I. zobellii KMM $231^{\mathrm{T}}$ (Ivanova et al., 2000). +, Positive; -, negative; ND, no data available. All species are non-fermentative, Gram-negative rods that require $\mathrm{NaCl}$ for growth and grow at $15-30{ }^{\circ} \mathrm{C}$.

\begin{tabular}{|c|c|c|c|c|c|c|c|c|c|c|c|c|c|}
\hline Characteristic & 1 & 2 & 3 & 4 & 5 & 6 & 7 & 8 & 9 & 10 & 11 & 12 & 13 \\
\hline Monotrichous flagellation & - & - & - & - & $\mathrm{ND}$ & + & + & + & + & + & + & + & + \\
\hline Production of $\mathrm{H}_{2} \mathrm{~S}$ & - & - & - & - & $\mathrm{ND}$ & + & + & $\mathrm{ND}$ & + & ND & + & $\mathrm{ND}$ & $\mathrm{ND}$ \\
\hline \multicolumn{14}{|l|}{ Hydrolysis of: } \\
\hline Aesculin & - & - & $\mathrm{ND}$ & + & - & + & + & - & + & + & + & - & - \\
\hline DNA & + & - & - & - & + & + & ND & $\mathrm{ND}$ & + & + & + & + & + \\
\hline Gelatin & + & + & + & + & - & + & + & + & + & - & + & - & - \\
\hline Tween 80 & - & - & + & + & + & + & + & + & + & + & + & - & - \\
\hline \multicolumn{14}{|l|}{ Growth at: } \\
\hline $4{ }^{\circ} \mathrm{C}$ & - & - & - & - & + & + & - & + & + & + & - & + & + \\
\hline $10{ }^{\circ} \mathrm{C}$ & + & + & - & - & + & + & + & + & + & + & - & + & + \\
\hline Growth in $15 \% \mathrm{NaCl}$ & + & + & + & - & - & + & - & + & + & + & + & + & - \\
\hline $\mathrm{NaCl}$ optimum (\%) & $2-5$ & $2-5$ & $1-8$ & $1-4$ & $2-3$ & $3-5$ & $3-6$ & $7.5-10$ & $3-5$ & $7-10$ & $3-5$ & $3-6$ & $3-6$ \\
\hline Growth at $\mathrm{pH} 6$ & + & + & - & - & + & + & $\mathrm{ND}$ & $\mathrm{ND}$ & + & + & + & + & + \\
\hline \multicolumn{14}{|l|}{ Susceptibility to: } \\
\hline Ampicillin & + & + & $\mathrm{ND}$ & + & - & $\mathrm{ND}$ & $\mathrm{ND}$ & $\mathrm{ND}$ & + & $\mathrm{ND}$ & + & - & - \\
\hline Carbenicillin & - & + & $\mathrm{ND}$ & + & - & $\mathrm{ND}$ & $\mathrm{ND}$ & $\mathrm{ND}$ & + & $\mathrm{ND}$ & + & - & - \\
\hline Chloramphenicol & + & - & $\mathrm{ND}$ & + & + & $\mathrm{ND}$ & $\mathrm{ND}$ & $\mathrm{ND}$ & + & $\mathrm{ND}$ & + & $\mathrm{ND}$ & $\mathrm{ND}$ \\
\hline Cephalothin & + & - & $\mathrm{ND}$ & + & - & $\mathrm{ND}$ & $\mathrm{ND}$ & $\mathrm{ND}$ & $\mathrm{ND}$ & ND & $\mathrm{ND}$ & $\mathrm{ND}$ & $\mathrm{ND}$ \\
\hline Novobiocin & - & - & $\mathrm{ND}$ & + & - & $\mathrm{ND}$ & $\mathrm{ND}$ & ND & $\mathrm{ND}$ & $\mathrm{ND}$ & $\mathrm{ND}$ & $\mathrm{ND}$ & $\mathrm{ND}$ \\
\hline $\begin{array}{l}\text { DNA G }+C \text { content } \\
(\mathrm{mol} \%)\end{array}$ & 46.6 & 46.9 & 50.0 & $48.6-49.3$ & 53.9 & 45.1 & 49.7 & 47.4 & 46.0 & 45.0 & 48.7 & 50.4 & 48.0 \\
\hline
\end{tabular}


Cells are Gram-negative, rod-shaped, approximately 2.5$3.0 \mu \mathrm{m}$ long and $0.5-0.9 \mu \mathrm{m}$ wide, and non-motile. Colonies on PY agar plates at $30{ }^{\circ} \mathrm{C}$ for 7 days are approximately $4-6 \mathrm{~mm}$ in diameter, off-white, circular, convex and non-luminescent, with entire edges. Endospores are absent. Poly- $\beta$-hydroxybutyrate is not accumulated as an intracellular reserve product. Nitrate is not reduced to nitrite. Does not grow anaerobically by fermentation of glucose or other carbohydrates as substrates. $\mathrm{NaCl}$ is required for growth; growth occurs at $0.5-$ $15 \% \mathrm{NaCl}$, with optimum growth at $2-5 \%$. Growth occurs at $10-42{ }^{\circ} \mathrm{C}$, with optimum growth at $30-35{ }^{\circ} \mathrm{C}$; does not grow at 4 or $45^{\circ} \mathrm{C}$. Growth occurs at $\mathrm{pH}$ values between 6 and 10 , with optimum growth at $\mathrm{pH} 7-8$; does not grow at $\mathrm{pH}$ 5. Oxidase- and catalase-positive, but negative for arginine dihydrolase, lysine decarboxylase and ornithine decarboxylase. $\mathrm{H}_{2} \mathrm{~S}$ is not produced from thiosulphate. DNA and gelatin are hydrolysed, but aesculin, agar, alginate, casein, starch, Tween 80 and urea are not. The following constitutive enzyme activities are positive in API ZYM tests: acid phosphatase, alkaline phosphatase, esterase (C4), esterase lipase (C8), lipase (C14), leucine arylamidase, valine arylamidase, cystine arylamidase, $\alpha$-chymotrypsin, naphthol-AS-BI-phosphohydrolase (weakly positive) and trypsin. No reactions are observed in API $50 \mathrm{CH}$ and Biolog GN2 tests. Isoprenoid quinones comprise Q-8 (95.2\%) and Q-7 (4.8\%). Cellular fatty acids present at levels of more than $3 \%$ include iso- $\mathrm{C}_{17: 0}$, iso- $\mathrm{C}_{15: 0}$, iso- $\mathrm{C}_{17: 1} \omega 9 c, \mathrm{C}_{18: 0}, \mathrm{C}_{18: 1} \omega 7 c$, iso- $\mathrm{C}_{11: 0} 3-\mathrm{OH}$, $\mathrm{C}_{16: 0}, \mathrm{C}_{16: 1} \omega 7 c$ and/or iso- $\mathrm{C}_{15: 0} 2-\mathrm{OH}$, iso- $\mathrm{C}_{19: 0}$, iso$\mathrm{C}_{15: 1} \mathrm{~F}$ and iso- $\mathrm{C}_{13: 0}$ 3-OH. Susceptible to ampicillin $(10 \mu \mathrm{g})$, cephalothin $(30 \mu \mathrm{g})$, chloramphenicol $(30 \mu \mathrm{g})$, colistin $(10 \mu \mathrm{g})$, nalidixic acid $(30 \mu \mathrm{g})$, and polymyxin $\mathrm{B}$ $(300 \mathrm{U})$, and intermediately susceptible to penicillin $\mathrm{G}$ $(10 \mathrm{U})$, tetracycline $(30 \mu \mathrm{g})$ and vancomycin $(30 \mu \mathrm{g})$. Resistant to carbenicillin $(100 \mu \mathrm{g})$, clindamycin $(2 \mu \mathrm{g})$, erythromycin $(15 \mu \mathrm{g})$, gentamicin $(10 \mu \mathrm{g})$, kanamycin $(30 \mu \mathrm{g})$, lincomycin $(2 \mu \mathrm{g})$, neomycin $(30 \mu \mathrm{g})$, novobiocin $(30 \mu \mathrm{g})$, oxacillin $(1 \mu \mathrm{g})$ and streptomycin $(10 \mu \mathrm{g})$.

The type strain, $\mathrm{PIM}^{\mathrm{T}}\left(=\mathrm{BCRC} 17749^{\mathrm{T}}=\mathrm{JCM} 15083^{\mathrm{T}}\right)$, was isolated from shallow coastal seawater of An-Ping Harbour, Tainan, Taiwan. The DNA G $+\mathrm{C}$ content of the type strain is $46.6 \mathrm{~mol} \%$.

\section{Description of Pseudidiomarina tainanensis sp. nov.}

Pseudidiomarina tainanensis (tai.nan.en'sis. N.L. fem. adj. tainanensis pertaining to Tainan, Taiwan, where the type strain was isolated).

Cells are Gram-negative, rod-shaped, approximately 2.5$3.2 \mu \mathrm{m}$ long and $0.6-0.9 \mu \mathrm{m}$ wide, and non-motile. Colonies on PY agar plates at $30{ }^{\circ} \mathrm{C}$ for 7 days are approximately 3-6 $\mathrm{mm}$ in diameter, yellow in colour, circular, convex and non-luminescent, with entire edges. Endospores are absent. Poly- $\beta$-hydroxybutyrate is not accumulated as an intracellular reserve product. Nitrate is not reduced to nitrite. Does not grow anaerobically by fermentation of glucose or other carbohydrates as substrates. $\mathrm{NaCl}$ is required for growth; growth occurs at $0.5-15 \%$ $\mathrm{NaCl}$, with optimum growth at $2-5 \%$. Growth occurs at 10 $42{ }^{\circ} \mathrm{C}$, with optimum growth at $30-35{ }^{\circ} \mathrm{C}$; does not grow at 4 or $45{ }^{\circ} \mathrm{C}$. Growth occurs at $\mathrm{pH}$ values between 6 and 10, with optimum growth at $\mathrm{pH} 7-8$; does not grow at $\mathrm{pH} 5$. Oxidase- and catalase-positive, but negative for arginine dihydrolase, lysine decarboxylase and ornithine decarboxylase. $\mathrm{H}_{2} \mathrm{~S}$ is not produced from thiosulphate. Gelatin is hydrolysed, but aesculin, agar, alginate, casein, DNA, starch, Tween 80 and urea are not. The following constitutive enzyme activities are positive in API ZYM tests: acid phosphatase, alkaline phosphatase, esterase (C4), esterase lipase (C8), lipase (C14), leucine arylamidase, valine arylamidase, cystine arylamidase, $\alpha$-chymotrypsin, naphthol-AS-BI-phosphohydrolase (weakly positive) and trypsin. No reactions are observed in API $50 \mathrm{CH}$ and Biolog GN2 tests. Isoprenoid quinones comprise Q-8 $(97.1 \%)$ and Q-7 (2.9\%). Cellular fatty acids present at levels of more than $3 \%$ include iso- $\mathrm{C}_{15: 0}$, iso- $\mathrm{C}_{17: 0}$, iso- $\mathrm{C}_{17: 1} \omega 9 c$, iso$\mathrm{C}_{11: 0} 3-\mathrm{OH}, \mathrm{C}_{18: 0}$, iso- $\mathrm{C}_{13: 0} 3-\mathrm{OH}$, iso- $\mathrm{C}_{19: 0}, \mathrm{C}_{16: 1} \omega 7 c$ and/or iso- $\mathrm{C}_{15: 0} 2-\mathrm{OH}, \mathrm{C}_{16: 0}$ and $\mathrm{C}_{18: 1} \omega 7 c$. Susceptible to ampicillin $(10 \mu \mathrm{g})$, carbenicillin $(100 \mu \mathrm{g})$, colistin $(10 \mu \mathrm{g})$ and polymyxin $\mathrm{B}(300 \mathrm{U})$, and intermediately susceptible to erythromycin $(15 \mu \mathrm{g})$, gentamicin $(10 \mu \mathrm{g})$, nalidixic acid $(30 \mu \mathrm{g})$ and neomycin $(30 \mu \mathrm{g})$. Resistant to cephalothin $(30 \mu \mathrm{g})$, chloramphenicol $(30 \mu \mathrm{g})$, clindamycin $(2 \mu \mathrm{g})$, kanamycin $(30 \mu \mathrm{g})$, lincomycin $(2 \mu \mathrm{g})$, novobiocin $(30 \mu \mathrm{g})$, oxacillin $(1 \mu \mathrm{g})$, penicillin $\mathrm{G}(10 \mathrm{U})$, streptomycin $(10 \mu \mathrm{g})$, tetracycline $(30 \mu \mathrm{g})$ and vancomycin $(30 \mu \mathrm{g})$.

The type strain, $\mathrm{PIN1}^{\mathrm{T}}\left(=\mathrm{BCRC} 17750^{\mathrm{T}}=\mathrm{JCM} 15084^{\mathrm{T}}\right)$, was isolated from shallow coastal seawater of An-Ping Harbour, Tainan, Taiwan. The DNA G $+\mathrm{C}$ content of the type strain is $46.9 \mathrm{~mol} \%$.

\section{Description of Pseudidiomarina homiensis (Kwon et al. 2006) comb. nov.}

Pseudidiomarina homiensis (ho.mi.en'sis. N.L. fem. adj. homiensis referring to the Homi Cape in Korea, where the type strain was isolated).

Basonym: Idiomarina homiensis Kwon et al. 2006.

The description is the same as that given for Idiomarina homiensis by Kwon et al. (2006). The type strain is PO-M2 ${ }^{\mathrm{T}}$ $\left(=\right.$ DSM $17923^{\mathrm{T}}=$ KACC $\left.11514^{\mathrm{T}}\right)$.

\section{Description of Pseudidiomarina salinarum (Yoon et al. 2007) comb. nov.}

Pseudidiomarina salinarum (sa.li.na'rum. L. gen. pl. n. salinarum of salt-works).

Basonym: Idiomarina salinarum Yoon et al. 2007.

The description is the same as that given for Idiomarina salinarum by Yoon et al. (2007). The type strain is ISL-52 $\left(=\right.$ CCUG $54359^{\mathrm{T}}=$ KCTC $\left.12971^{\mathrm{T}}\right)$. 


\section{Acknowledgements}

We thank Dr J.-S. Chen, College of Health Care, China Medical University, Taiwan, for advice and critical reading of the manuscript. We also thank Ssu-Po Huang for the analysis of isoprenoid quinones. This study was supported by grants NSC94-2211-E-426-001, NSC942313-B-002-066 and NSC95-2221-E-426-005-MY2 from the National Science Council, Taiwan.

\section{References}

Brettar, I., Christen, R. \& Höfle, M. G. (2003). Idiomarina baltica sp. nov., a marine bacterium with a high optimum growth temperature isolated from surface water of the central Baltic Sea. Int J Syst Evol Microbiol 53, 407-413.

Choi, D. H. \& Cho, B. C. (2005). Idiomarina seosinensis sp. nov., isolated from hypersaline water of a solar saltern in Korea. Int J Syst Evol Microbiol 55, 379-383.

Donachie, S. P., Hou, S., Gregory, T. S., Malahoff, A. \& Alam, M. (2003). Idiomarina loihiensis sp. nov., a halophilic $\gamma$-Proteobacterium from the Lō'ihi submarine volcano, Hawai'i. Int J Syst Evol Microbiol 53, 1873-1879.

Fesefeldt, A., Kloos, K., Bothe, H., Lemmer, H. \& Gliesche, C. G. (1998). Distribution of denitrification and nitrogen fixation genes in Hyphomicrobium spp. and other budding bacteria. Can J Microbiol 44, 181-186.

Hu, Z.-Y. \& Li, Y. (2007). Pseudidiomarina sediminum sp. nov., a marine bacterium isolated from coastal sediments of Luoyuan Bay in China. Int J Syst Evol Microbiol 57, 2572-2577.

Ivanova, E. P., Romanenko, L. A., Chun, J., Matte, M. H., Matte, G. R., Mikhailov, V. V., Svetashev, V. I., Huq, A., Maugel, T. \& Colwell, R. R. (2000). Idiomarina gen. nov., comprising novel indigenous deep-sea bacteria from the Pacific Ocean, including descriptions of two species, Idiomarina abyssalis sp. nov. and Idiomarina zobellii sp. nov. Int J Syst Evol Microbiol 50, 901-907.

Ivanova, E. P., Flavier, S. \& Christen, R. (2004). Phylogenetic relationships among marine Alteromonas-like proteobacteria: emended description of the family Alteromonadaceae and proposal of Pseudoalteromonadaceae fam. nov., Colwelliaceae fam. nov.
Shewanellaceae fam. nov., Moritellaceae fam. nov., Ferrimonadaceae fam. nov., Idiomarinaceae fam. nov. and Psychromonadaceae fam. nov. Int J Syst Evol Microbiol 54, 1773-1788.

Jean, W. D., Shieh, W. Y. \& Chiu, H.-H. (2006). Pseudidiomarina taiwanensis gen. nov., sp. nov., a marine bacterium isolated from shallow coastal water of An-Ping Harbour, Taiwan, and emended description of the family Idiomarinaceae. Int J Syst Evol Microbiol 56, 899-905.

Kwon, S.-W., Kim, B.-Y., Weon, H.-Y., Baek, Y.-K., Koo, B.-S. \& Go, S.-J. (2006). Idiomarina homiensis sp. nov., isolated from seashore sand in Korea. Int J Syst Evol Microbiol 56, 2229-2233.

Martínez-Cánovas, M. J., Béjar, V., Martínez-Checa, F., Páez, R. \& Quesada, E. (2004). Idiomarina fontislapidosi sp. nov. and Idiomarina ramblicola sp. nov., isolated from inland hypersaline habitats in Spain. Int J Syst Evol Microbiol 54, 1793-1797.

Sasser, M. (1997). Identification of bacteria by gas chromatography of cellular fatty acids, MIDI Technical Note 101. Newark, DE: MIDI Inc.

Shieh, W. Y. \& Liu, C. M. (1996). Denitrification by a novel halophilic fermentative bacterium. Can J Microbiol 42, 507-514.

Shieh, W. Y., Chen, A.-L. \& Chiu, H.-H. (2000). Vibrio aerogenes sp. nov., a facultatively anaerobic, marine bacterium that ferments glucose with gas production. Int J Syst Evol Microbiol 50, 321-329.

Shieh, W. Y., Lin, Y.-T. \& Jean, W. D. (2004). Pseudovibrio denitrificans gen. nov., sp. nov., a marine, facultatively anaerobic, fermentative bacterium capable of denitrification. Int J Syst Evol Microbiol 54, 2307-2312.

Shieh, W. Y., Liu, T. Y., Lin, S. Y., Jean, W. D. \& Chen, J.-S. (2008). Simiduia agarivorans gen. nov., sp. nov., a marine agarolytic bacterium isolated from shallow coastal water from Keelung, Taiwan. Int J Syst Evol Microbiol 58, 895-900.

Smibert, R. M. \& Krieg, N. R. (1994). Phenotypic characterization. In Methods for General and Molecular Bacteriology, pp. 607-654. Edited by P. Gerhardt, R. G. E. Murray, W. A. Wood \& N. R. Krieg. Washington, DC: American Society for Microbiology.

Yoon, J.-H., Jung, S.-Y., Jung, Y.-T. \& Oh, T.-K. (2007). Idiomarina salinarum sp. nov., isolated from a marine solar saltern in Korea. Int $J$ Syst Evol Microbiol 57, 2503-2506. 